\title{
Development and ex post validation of prediction equations of corn energy values for growing pigs
}

\section{Determinação e validação ex post de equações de predição dos valores energéticos do milho para suínos em crescimento}

\author{
Everardo Ayres Correia Ellery ${ }^{1}$; Pedro Henrique Watanabe ${ }^{2 *}$; \\ Luiz Euquerio Carvalho'; Teresinha Marisa Bertol3; Ednardo Rodrigues Freitas ${ }^{2}$; \\ Thalles Ribeiro Gomes ${ }^{4}$; Emanuela Lima de Oliveira ${ }^{4}$; Rafael Carlos Nepomuceno ${ }^{4}$
}

\begin{abstract}
The aim of this study was to determine and validate prediction equations for digestible (DE) and metabolizable energy (ME) of corn for growing pigs. The prediction equations were developed based on data on the chemical composition, digestible and metabolizable energy of corn grain (30 samples) evaluated in experiments in Embrapa Suínos e Aves, Brazil. The equations were evaluated using regression analysis, and adjusted $\mathrm{R}^{2}$ was the criterion for selection of the best models. Two equations were tested for $\mathrm{DE}$ and $\mathrm{ME}$, each. To validate the equations, 1 experiment with 2 assays was performed to determine the values of $\mathrm{DE}$ and $\mathrm{ME}$ of 5 corn cultivars. In each assay, we used 24 growing pigs with initial average weight of $54.21 \pm 1.68 \mathrm{~kg}$ in complete randomized block design with 6 treatments and 4 replicates. Treatments consisted of a reference diet and 5 ration tests composed of $60 \%$ of the reference diet and $40 \%$ of corn ( 1 of the 5 cultivars). Based on the results of the metabolic experiment and predicted values obtained in the equations, the validation of the equations was conducted using the lowest prediction error $\left(\mathrm{p}_{\mathrm{e}}\right)$ as a criterion for selection. The equations that produced the most accurate estimates of $\mathrm{DE}$ and $\mathrm{ME}$ of corn were as follows: $\mathrm{DE}=11812-1015.9 \mathrm{CP}-837.9 \mathrm{EE}-1641 \mathrm{ADF}$ $+2616.3 \mathrm{Ash}+47.5\left(\mathrm{CP}^{2}\right)+114.7\left(\mathrm{CF}^{2}\right)+46\left(\mathrm{ADF}^{2}\right)-1.6\left(\mathrm{NDF}^{2}\right)-997.1\left(\mathrm{Ash}^{2}\right)+151.9 \mathrm{EECF}+$ 23.2EENDF - 126.4CPCF + 136.4CPADF - 4.0CPNDF, with $\mathrm{R}^{2}=0.81$ and $\mathrm{p}_{\mathrm{e}}=2.33$; $\mathrm{ME}=12574-$ 1254.9CP $-1140.5 \mathrm{EE}-1359.9 \mathrm{ADF}+2816.3 \mathrm{Ash}+77.6\left(\mathrm{CP}^{2}\right)+92.3\left(\mathrm{CF}^{2}\right)+54.1\left(\mathrm{ADF}^{2}\right)-1.8\left(\mathrm{NDF}^{2}\right)$ $-1097.2\left(\mathrm{Ash}^{2}\right)+240.6 \mathrm{EECF}+26.3 \mathrm{EENDF}-157.4 \mathrm{CPCF}+96.5 \mathrm{CPADF}-4.4 \mathrm{CPNDF}$, with $\mathrm{R}^{2}=0.89$ and $\mathrm{p}_{\mathrm{e}}=2.24$. Thus, using the data on chemical composition, it is possible to derive prediction equations for $\mathrm{DE}$ and $\mathrm{ME}$ of corn for pigs; these equations seem to be valid because of the small prediction errors suggestive of high accuracy of these models.
\end{abstract}

Key words: Digestible energy, metabolizable energy, mathematical model

\section{Resumo}

Objetivou-se determinar e validar equações de predição para energia digestível (ED) e metabolizável (EM) do milho para suínos em crescimento. Foram utilizados dados de composição química e de digestibilidade e metabolizabilidade de 30 amostras de grãos de milho avaliadas em experimentos na Embrapa Suínos e Aves, sendo as equações estimadas por meio da análise de regressão e o $\mathrm{R}^{2}$ ajustado

\footnotetext{
1 Mestre em Zootecnia, Universidade Federal do Ceará, UFC, Fortaleza, CE, Brasil. E-mail: everardo.ellery@zootecnista.com.br

2 Profs., Dept ${ }^{\circ}$ de Zootecnia, UFC, Fortaleza, CE, Brasil. E-mail: pedro_watanabe@yahoo.com.br; euquerio@ufc.br; ednardo@ ufc.br

3 Pesquisadora da Embrapa Suínos e Aves, Concórdia, SC, Brasil. E-mail: teresinha.bertol@embrapa.br

4 Discentes de Doutorado em Zootecnia, UFC, Fortaleza, CE, Brasil. E-mail: thalleszoo@yahoo.com.br; lima.emanuela@gmail. com; rafael@zootecnista.com.br

* Author for correpondence
} 
como critério para selecionar os melhores modelos. Para a validação das equações, foi realizado um experimento com dois ensaios para a determinação dos valores de ED e EM dos grãos de milho de cinco cultivares. Em cada ensaio, 24 leitões machos castrados com peso médio inicial de 54,21 1 1,68 $\mathrm{kg}$ foram distribuídos em um delineamento em blocos ao acaso, com 6 tratamentos e 4 repetições. Os tratamentos foram uma ração referência e cinco rações testes, compostas por $60 \%$ da ração referência e $40 \%$ do milho de cada um dos cinco diferentes cultivares. A partir dos resultados do experimento e dos valores preditos pelas equações, procedeu-se a validação das equações, sendo o critério de seleção o menor erro de predição. As equações que melhor se ajustaram para os valores de ED e EM do milho foram: $\mathrm{ED}=11812-1015,9(\mathrm{~PB})-837,9(\mathrm{EE})-1641(\mathrm{FDA})+2616,3(\mathrm{MM})+47,5\left(\mathrm{~PB}^{2}\right)+114,7\left(\mathrm{FB}^{2}\right)+$ $46\left(\mathrm{FDA}^{2}\right)-1,6\left(\mathrm{FDN}^{2}\right)-997,1\left(\mathrm{MM}^{2}\right)+151,9(\mathrm{EEFB})+23,2(\mathrm{EEFDN})-126,4(\mathrm{PBFB})+136,4(\mathrm{PBFDA})$ $-4,0(\mathrm{PBFDN})$, com $\mathrm{R}^{2=} 0,81$ e $\mathrm{e}_{\mathrm{p}}=2,33 ; \mathrm{EM}=12574-1254,9(\mathrm{~PB})-1140,5(\mathrm{EE})-1359,9(\mathrm{FDA})+$ $2816,3(\mathrm{MM})+77,6\left(\mathrm{~PB}^{2}\right)+92,3\left(\mathrm{FB}^{2}\right)+54,1\left(\mathrm{FDA}^{2}\right)-1,8\left(\mathrm{FDN}^{2}\right)-1097,2\left(\mathrm{MM}^{2}\right)+240,6(\mathrm{EEFB})+$ $26,3(\mathrm{EEFDN})-157,4(\mathrm{PBFB})+96,5(\mathrm{PBFDA})-4,4(\mathrm{PBFDN})$, com $\mathrm{R}^{2}=0,89$ e $\mathrm{e}_{\mathrm{p}}=2,24$. A partir dos dados de composição química, foi possível determinar equações de predição para os valores de ED e EM do milho para suínos, sendo estas validadas pelo menor erro de predição para maior acurácia dos modelos.

Palavras-chave: Energia digestível, energia metabolizável, modelos matemáticos

\section{Introduction}

In diets for pigs, corn is commonly used as a primary energy source, accounting for approximately $65 \%$ of metabolizable energy (ME) of a ration (CASTILHA et al., 2011). However, besides differences in chemical composition and variability caused by genetic variation (e.g., cultivars with high oil content, protein or lysine, among others; PEDROSO et al., 2006), there are differences in the energy values of corn. Consequently, to reduce feed costs and ensure higher production efficiency, the above factors necessitate metabolic assays to correct the nutritional and energy values of the feed used for ration formulation. On the other hand, these tests require time, infrastructure, and financial resources and are therefore onerous for the pig industry because of complexities of feed production (POZZA et al., 2008).

Faced with these difficulties, researchers developed indirect methods to estimate energy content of various types of feed for the animals. Among these methods, prediction equations have been prominent because they allow researchers to estimate the energy value of feed according to its composition (ZONTA et al., 2004). Nevertheless, the limited range of values in analytical parameters of samples makes it difficult to predict energy values of feedstuffs because this approach results in regression coefficients with high standard deviations and low reliability. Furthermore, analytical parameters of each feedstuff generally exhibit a high correlation with one another, creating problems of collinearity. Therefore, only a few parameters can be included in the equations, and the use of these is limited to the range of values observed in the experiment that was used to obtain them (CARRÉ, 1990).

Although many studies have been conducted to determine the relationships between chemical composition and energy values of feed, few studies have addressed the applicability of the developed equations; thus, accuracy of the existing equations is uncertain. In this sense, Pozza et al. (2008) did not obtain an adjustment of the prediction equations for digestible energy (DE) and ME of corn silage for pigs because of the nutritional variability. For the energy values of 4 cultivars of corn grain for pigs, Castilha et al. (2011) did not find appropriate $\mathrm{DE}$ equations but rather developed 2 equations to calculate ME based on the highest coefficient of determination. Nonetheless, the coefficient of determination obtained during development of the prediction equations allows for estimation of equation adjustments to the original data but does not necessarily show the accuracy of the equation for prediction of these values in a feedstuff or ration 
with the numbers different than the original data. Accordingly, the use of statistical methods has also increased the accuracy of prediction models and is recommended for validation. The classical validation tests for evaluation of quality of an estimated model are generally based on statistical considerations, such as cross-correlation analysis between input and the residue among others (AGUIRRE, 2004). Nevertheless, there may be undesirable cases when the correlation is strong and the prediction error is high. Thus, ex post validation using data not belonging to the original population should be advantageous for determining the prediction value by means of a new data set. Accordingly, the objective of the present study was to develop and validate prediction equations for $\mathrm{DE}$ and $\mathrm{ME}$ of corn for growing pigs.

\section{Materials and Methods}

The information used in this study was obtained from the data on DE and ME of different cultivars of corn grain (varieties and hybrids) used in pig diets; these data were determined in metabolism assays using the method of total collection of feces and urine carried out in the last 2 decades at the experimental-metabolism facilities for pigs in Embrapa Suínos e Aves, Concórdia-Santa Catarina, Brazil.

The data on 37 corn samples were catalogued in a spreadsheet with all the nutritional composition data as well as the energy values. For cataloguing, the information was selected, analyzed, and then compared with actual values from Tabelas Brasileiras para Aves e Suínos (ROSTAGNO et al., 2011) and NRC (2012), using only the datasets with information on crude protein $(\mathrm{CP})$, ether extract (EE), ash, crude fiber (CF), neutral-detergent fiber (NDF), and acid-detergent fiber (ADF) as well as $\mathrm{DE}$ and $\mathrm{ME}$ for pigs in the growing phase. From 37 database-derived corn samples, 30 samples were selected for development of the prediction equations for estimation of DE and ME.
Initially, Pearson correlations were estimated (DRAPER; SMITH, 1981) to elucidate the structure of relationships among the variables under study, using the CORR procedure of the Statistical Analysis System (SAS) software (SAS Institute, 2009). The prediction equations were evaluated using multiple regression analysis to determine the independent variables that resulted in significance in the model using the REG procedure of the SAS software. The adjusted coefficient of determination (adjusted $\mathrm{R}^{2}$ ) was the main criterion for selection of the best models. Among the equations that had higher adjusted $\mathrm{R}^{2}$, the final model was the equation that included the variables of interest as well as interactions between the variables for the best fit of the equations. Two models for DE and $\mathrm{ME}$, respectively, were selected for the validation procedure.

For ex post validation of prediction equations, an experiment with 2 metabolism assays was carried out to determine the values of DE and ME of 5 cultivars of corn grain. In each experiment, 24 pigs (MS-115 $\times$ F1) with initial weight of 54.21 $\pm 1.68 \mathrm{~kg}$ (mean $\pm \mathrm{SD}$ ) were housed in metabolic cages. It was used the method of total collection of feces and urine along with the randomized block design consisting of 6 treatments and 4 replicates. The experimental unit consisted of an individual animal. Each block was formed from a group of light and heavy animals. The treatments were a reference diet and 5 test diets composed of $60 \%$ of the reference diet and $40 \%$ of corn under study ( 1 of the 5 cultivars). The reference diet was formulated to meet the minimum nutritional requirements for high-genetic-potential barrows weighing $50-70 \mathrm{~kg}$ (ROSTAGNO et al., 2011). Each trial lasted 12 days, with the first 7 days intended to adapt the animals to the cages and to determine feed intake and the final 5 days intended for collection of feces and urine. The feeding took place twice daily: at $08 \mathrm{~h} 00$ and $14 \mathrm{~h} 00$. Thirty minutes after the start of the meal, the leftovers were collected and weighed for measurement of the amount ingested. Water was provided ad libitum after each meal. 
The amount of feed in the collection period was set according to the lowest consumption obtained during the first 7 days, based on metabolic weight $\left(\mathrm{W}^{0.75}\right)$ of each experimental unit. Ferric oxide $\left(\mathrm{Fe}_{2} \mathrm{O}_{3}\right)$ was used as a fecal marker $(0.5 \%$ in food $)$ to determine the beginning and end of the collection period. Feces were collected twice daily, weighed, and stored in a freezer at $-8^{\circ} \mathrm{C}$ until analysis. During the collection period, the urine of each animal produced within $24 \mathrm{~h}$ was collected daily in the morning into plastic buckets containing $20 \mathrm{~mL}$ of $2 \mathrm{~N}$ hydrochloric acid, to prevent the loss of nitrogen and to suppress proliferation of bacteria and fungi. The volume of urine produced was measured by withdrawing an aliquot of $20 \%$ (which was stored in a freezer at $-8^{\circ} \mathrm{C}$ ). At the end of the experiment, the urine and feces of each animal were thawed and homogenized to obtain a composite sample for each animal. Fecal samples were subjected to predrying at $55^{\circ} \mathrm{C}$ for $72 \mathrm{~h}$, with subsequent grinding in a Wiley mill with a $1-\mathrm{mm}$ sieve. The urine samples were dried in petri dishes in an oven with forced air circulation at $55^{\circ} \mathrm{C}$ for $72 \mathrm{~h}$, replenishing the volume of urine in the petri dishes every $24 \mathrm{~h}$. Rations and corn samples were ground and subjected to the same procedures described for the fecal samples above.

Analysis of chemical composition and gross energy of rations, feedstuffs, feces, and urine was performed at Laboratório de Análises FísicoQuimícas in Embrapa Suínos e Aves, according to AOAC (2005). The analysis of NDF and ADF was performed as described by Van Soest et al. (1991). Measurement of gross energy was performed in an adiabatic calorimeter (PARR, model 1241EA). Calculation of DE and ME of corn was based on the equation proposed by Matterson et al. (1965). After analysis, the selected equations were validated by subjecting them to regression analysis using the REG procedure of the SAS software, using the lowest prediction error $\left(\mathrm{p}_{\mathrm{e}}\right)$ as the validation criterion. This parameter was calculated from the difference between the predicted and observed values in the metabolizability assay for each corn cultivar. The accuracy was calculated using the mean squared prediction error and the mean prediction error.

\section{Results and Discussion}

Table 1 shows the mean, maximum, minimum, and standard deviations of the variables of chemical composition and energy of the 30 corn samples. Among the variables of chemical composition of corn for pigs (Table 2), there was a positive correlation between $\mathrm{CF}$ and $\mathrm{DE}(\mathrm{P}<0.05)$ and between $\mathrm{DE}$ and ME $(\mathrm{P}<0.01)$. Regarding the correlations among the variables of chemical composition and ME of corn for pigs, a significant effect $(\mathrm{P}<0.05)$ existed only for $\mathrm{CP}$.

To adjust the prediction equations to the DE of corn for growing pigs, it was used the values of $\mathrm{CP}$, $\mathrm{EE}, \mathrm{CF}, \mathrm{ADF}, \mathrm{NDF}$, and ash as well as the correlations among these (EE-CF, EE-NDF, CP-CF, CP-ADF, and $\mathrm{CP}-\mathrm{NDF}$ ). $\mathrm{CF}$ negatively correlated with $\mathrm{DE}$; this may be because of the reduced participation of this fraction in corn leading to increase in fiber content that ultimately results in lower energy and digestibility of nutrients. In this sense, Cowieson (2005) reported a high correlation between the DE and fiber; this correlation is an efficient predictor, corroborated by Anderson et al. (2012). Those authors state that the methods for measurement the fiber fraction of feed are not independent of each other, owing to the involvement of all resulting values in different fiber analyses for prediction of energy values of feedstuffs for pigs. 
Table 1. Average energy and chemical composition of 30 samples of corn (on the dry-matter basis).

\begin{tabular}{lcccc}
\hline Variable & Mean & Standard deviation & Minimum & Maximum \\
\hline DE $(\mathrm{kcal} / \mathrm{kg})$ & 3926 & 122.71 & 3636 & 4115 \\
ME $(\mathrm{kcal} / \mathrm{kg})$ & 3791 & 116.54 & 3583 & 4005 \\
CP (\%) & 8.82 & 0.70 & 7.74 & 11.22 \\
EE (\%) & 4.20 & 0.56 & 3.19 & 5.99 \\
CF (\%) & 2.71 & 0.73 & 1.66 & 3.88 \\
ADF (\%) & 4.28 & 1.21 & 2.96 & 8.27 \\
NDF (\%) & 20.59 & 7.47 & 10.46 & 40.46 \\
Ash (\%) & 1.24 & 0.17 & 0.66 & 1.56 \\
\hline
\end{tabular}

DE: digestible energy; ME: metabolizable energy; CP: crude protein; EE: ether extract; CF: crude fiber; ADF: acid-detergent fiber; NDF: neutral-detergent fiber.

Table 2. Correlation coefficients among variables of chemical composition and energy content of 30 samples of corn.

\begin{tabular}{llllccccc}
\hline & DE & ME & CP & EE & CF & ADF & NDF & Ash \\
\hline DE & 1.000 & & & & & & & \\
ME & $0.878^{* *}$ & 1.000 & & & & & & \\
CP & 0.211 & $0.351^{*}$ & 1.000 & & & & & \\
EE & 0.032 & -0.053 & 0.061 & 1.000 & & & & \\
CF & $-0.404^{*}$ & 0.331 & 0.289 & -0.068 & 1.000 & & & \\
ADF & 0.308 & 0.287 & 0.148 & -0.295 & $0.737^{* *}$ & 1.000 & & \\
NDF & 0.041 & -0.073 & 0.178 & $0.357^{*}$ & 0.110 & 0.104 & 1.000 & \\
Ash & 0.316 & 0.314 & $0.369^{*}$ & -0.044 & -0.129 & -0.016 & 0.189 & 1.000 \\
\hline
\end{tabular}

DE: digestible energy (kcal/kg); ME: metabolizable energy (kcal/kg); CP: crude protein (\%); EE: ether extract (\%); CF: crude fiber (\%); ADF: acid detergent fiber (\%); NDF: neutral detergent fiber $(\%)$.

*t test: $\mathrm{P}<0.05$

$* *$ t test: $\mathrm{P}<0.01$.

To adjust ME of corn for growing pigs, weit was used values of $\mathrm{CP}, \mathrm{EE}, \mathrm{CF}, \mathrm{ADF}, \mathrm{NDF}$, and ash as well as the correlations among them (EE-CF, EENDF, CP-CF, CP-ADF, and CP-NDF). The positive correlation between $\mathrm{ME}$ and $\mathrm{CP}$ may be attributed to protein quality: when the quality of protein is low, ME decreases because the amino acids are not used for protein synthesis; instead they are catabolized and used as energy sources, while nitrogen is excreted with urine (POZZA et al., 2008).

The prediction equations that produced the most accurate estimate of DE of corn for growing pigs were the following: $\mathrm{DE}_{1}=11812-1015.9 \mathrm{CP}-837.9 \mathrm{EE}-$ $1641 \mathrm{ADF}+2616.3 \mathrm{Ash}+47.5\left(\mathrm{CP}^{2}\right)+114.7\left(\mathrm{CF}^{2}\right)+$ $46\left(\mathrm{ADF}^{2}\right)-1.6\left(\mathrm{NDF}^{2}\right)-997.1\left(\mathrm{Ash}^{2}\right)+151.9 \mathrm{EECF}$ $+23.2 \mathrm{EENDF}-126.4 \mathrm{CPCF}+136.4 \mathrm{CPADF}-$
4.0CPNDF, with $\mathrm{R}^{2}=0.81$ and adjusted $\mathrm{R}^{2}=0.53$; $\mathrm{DE}_{2}=9119-367.6 \mathrm{CP}-748.5 \mathrm{EE}-1897.2 \mathrm{ADF}+$ $2799.1 \mathrm{Ash}+100.6\left(\mathrm{CF}^{2}\right)+39.8\left(\mathrm{ADF}^{2}\right)-1.2\left(\mathrm{NDF}^{2}\right)$ $-1061.5\left(\mathrm{Ash}^{2}\right)+151.2 \mathrm{EECF}+19.2 \mathrm{EENDF}-$ 117.8CPCF + 174.1CPADF - 3.5CPNDF, with $\mathrm{R}^{2}=$ 0.78 and adjusted $\mathrm{R}^{2}=0.52$.

The prediction equations that produced the most accurate estimate of $\mathrm{ME}$ of corn for growing pigs were the following: $\mathrm{ME}_{1}=12574-1254.9 \mathrm{CP}$ - 1140.5EE $-1359.9 \mathrm{ADF}+$ 2816.3Ash + 77.6( $\left(\mathrm{CP}^{2}\right)+92.3\left(\mathrm{CF}^{2}\right)+54.1\left(\mathrm{ADF}^{2}\right)-1.8\left(\mathrm{NDF}^{2}\right)$ $-1097.2\left(\mathrm{Ash}^{2}\right)+240.6 \mathrm{EECF}+26.3 \mathrm{EENDF}-$ 157.4CPCF + 96.5CPADF - 4.4CPNDF, with $\mathrm{R}^{2}=0.89$ and adjusted $\mathrm{R}^{2}=0.73 ; \mathrm{ME}_{2}=14694-$ 971.1CP - 3091.9EE - 1190.5ADF + 3643.4Ash + $57.2\left(\mathrm{CP}^{2}\right)+215\left(\mathrm{EE}^{2}\right)+43.3\left(\mathrm{ADF}^{2}\right)-1.7\left(\mathrm{NDF}^{2}\right)$ 
- 1410.1( $\left.\mathrm{Ash}^{2}\right)+$ 347.4EECF + 15.8EENDF 148.7CPCF + 86.7CPADF, with $\mathrm{R}^{2}=0.86$ and adjusted $\mathrm{R}^{2}=0.70$.

In the selected equations, the best fit was due to the higher adjusted $\mathrm{R}^{2}$ and $\mathrm{R}^{2}$, in agreement with Nascimento et al. (2011), who also reported an increase in $\mathrm{R}^{2}$ with the increase in the number of variables in the equation. The use of prediction equations for $\mathrm{ME}$ of corn that are based on composition of DE was proposed by Noblet and Perez (1993) and Castilha et al. (2011), although they used fewer variables. This approach is inconvenient because of the necessity to determine the amount of energy obtained in a calorimeter and to perform a digestibility assay. The use of prediction equations for DE (or ME) that consist of only 1 variable of chemical composition or a combination of a reduced number of variables is the most desirable; however, it was found that the coefficients of determination $\left(\mathrm{R}^{2}\right)$ are reduced; the equations proposed by Wiseman and Cole (1985) have $\mathrm{R}^{2}$ of the equations for DE between 0.63 and 0.24 , and for ME, between 0.34 and 0.20. Thus, the energy value of a feedstuff is a function of the levels of lipids, carbohydrates, and proteins as well as antinutritional factors, such as fibers. Therefore, the prediction equations for DE and ME of feed generally consist of 1 or a combination of variables of the chemical composition (COSTA et al., 2005).

Table 3 describes the results of the metabolism assay in terms of chemical composition and energy values of the 5 corn cultivars. Table 4 shows the coefficients of determination $\left(\mathrm{R}^{2}\right.$ and adjusted $\mathrm{R}^{2}$ ) and prediction error $\left(\mathrm{p}_{\mathrm{e}}\right)$ of the equations for estimation of energy of corn for growing pigs. Although the coefficients of determination of the selected equations are high, the equations that produce the most accurate estimates of DE and ME, with the lowest $\mathrm{p}_{\mathrm{e}}$, were the following:

$$
\begin{aligned}
& \mathrm{DE}=11812-1015.9 \mathrm{CP}-837.9 \mathrm{EE}-1641 \mathrm{ADF} \\
& +2616.3 \mathrm{Ash}+47.5\left(\mathrm{CP}^{2}\right)+114.7\left(\mathrm{CF}^{2}\right)+46\left(\mathrm{ADF}^{2}\right) \\
& -1.6\left(\mathrm{NDF}^{2}\right)-997.1\left(\mathrm{Ash}^{2}\right)+151.9 \mathrm{EECF}+ \\
& \text { 23.2EENDF }-126.4 \mathrm{CPCF}+136.4 \mathrm{CPADF}- \\
& \text { 4.0CPNDF, with } \mathrm{R}^{2}=0.81 \text { and } \mathrm{p}_{\mathrm{e}}=2.33
\end{aligned}
$$

$$
\mathrm{ME}=12574-1254.9 \mathrm{CP}-1140.5 \mathrm{EE}-
$$
1359.9ADF + 2816.3Ash + 77.6(CP $\left.\mathrm{CP}^{2}\right)+92.3\left(\mathrm{CF}^{2}\right)$ + 54.1( $\left(\mathrm{ADF}^{2}\right)-1.8\left(\mathrm{NDF}^{2}\right)-1097.2\left(\mathrm{Ash}^{2}\right)+$ 240.6EECF $+26.3 \mathrm{EENDF}-157.4 \mathrm{CPCF}+$ 96.5CPADF - 4.4CPNDF, with $\mathrm{R}^{2}=0.89$ and $\mathrm{p}_{\mathrm{e}}=$ 2.24 .

Table 3. Chemical composition and energy of 5 cultivars of corn used in the metabolizability assays (on the dry-matter basis).

\begin{tabular}{cccccccccc}
\hline Corn cultivar & DM & DE & ME & CP & EE & CF & ADF & NDF & Ash \\
\hline $\mathbf{1}$ & 88.32 & 3687 & 3622 & 8.51 & 4.19 & 2.47 & 3.33 & 21.08 & 1.06 \\
$\mathbf{2}$ & 86.89 & 4036 & 3864 & 8.91 & 4.87 & 3.20 & 5.34 & 19.02 & 1.38 \\
$\mathbf{3}$ & 89.32 & 3843 & 3792 & 9.17 & 4.00 & 1.91 & 2.96 & 21.52 & 1.40 \\
$\mathbf{4}$ & 86.66 & 4057 & 4005 & 10.15 & 3.77 & 2.60 & 4.56 & 17.37 & 1.48 \\
$\mathbf{5}$ & 89.87 & 3974 & 3838 & 8.29 & 4.15 & 2.40 & 3.49 & 21.23 & 1.15 \\
\hline
\end{tabular}

DM: dry matter (\%); DE: digestible energy (kcal/kg); ME: metabolizable energy (kcal/kg); CP: crude protein (\%); EE: ether extract $(\%)$; CF: crude fiber (\%); ADF: acid-detergent fiber (\%); NDF: neutral-detergent fiber (\%). 
Table 4. Coefficients of determination, the coefficient of variation (CV), prediction error, and accuracy of the prediction equations for estimation of energy of corn for growing pigs.

\begin{tabular}{ccccccc}
\hline Equation & $\mathbf{R}^{\mathbf{2}}$ & Adjusted $\mathbf{R}^{\mathbf{2}}$ & P value & $\mathbf{C V} \mathbf{( \% )}$ & $\begin{array}{c}\text { Prediction error } \\
\mathbf{( \% )}\end{array}$ & $\begin{array}{c}\text { Accuracy } \\
\text { (kcal/kg) }\end{array}$ \\
\hline $\mathrm{DE}_{1}$ & 0.81 & 0.53 & 0.04 & 2.07 & $2.33 \pm 2.31$ & $43.9 \pm 120.6$ \\
$\mathrm{DE}_{2}$ & 0.78 & 0.52 & 0.04 & 2.09 & $2.50 \pm 2.07$ & $32.9 \pm 126.4$ \\
$\mathrm{ME}_{1}$ & 0.89 & 0.73 & 0.005 & 1.56 & $2.24 \pm 1.31$ & $36.2 \pm 97.3$ \\
$\mathrm{ME}_{2}$ & 0.86 & 0.70 & 0.004 & 1.63 & $2.51 \pm 1.38$ & $51.7 \pm 102.5$ \\
\hline
\end{tabular}

The data in the last 2 columns are shown as mean $\pm \mathrm{SD}$. DE: digestible energy (kcal/kg); ME: metabolizable energy (kcal/kg).

From the equations tested, it was selected those that had higher $\mathrm{R}^{2}$ and adjusted $\mathrm{R}^{2}$, ensuring a smaller percentage difference between predicted and observed values (Table 5). Regarding the parameter of selection, the adjusted $\mathrm{R}^{2}$ has a lower value because of the incorporation of data that increases when a greater number of variables are added to the model. Nonetheless, both $\mathrm{R}^{2}$ and adjusted $\mathrm{R}^{2}$ are a measurement of correspondence of the values to the model, but the adjusted $\mathrm{R}^{2}$ is corrected by the number of degrees of freedom, eliminating the effect of inflation of $\mathrm{R}^{2}$ caused by the inclusion of more variables. In this case, addition of more data to the equation results in a decrease in the value of adjusted $\mathrm{R}^{2}$. Notably, after further validation, it was selected those equations that had higher $\mathrm{R}^{2}$ and adjusted $\mathrm{R}^{2}$.

Table 5. Observed and predicted values of digestible and metabolizable energy of corn for growing pigs (on the drymatter basis) and percentage differences between the predicted and observed values.

\begin{tabular}{ccccccc}
\hline & \multicolumn{2}{c}{ Observed values $(\mathbf{O})$} & \multicolumn{2}{c}{ Predicted values $(\mathbf{P r})$} & \multicolumn{2}{c}{ (Pr-O)/O*100 } \\
\hline Corn cultivar & DE (kcal/kg) & ME (kcal/kg) & DE $_{\mathbf{1}}(\mathbf{k c a l} / \mathbf{k g})$ & $\mathbf{M E}_{\mathbf{1}}(\mathbf{k c a l} / \mathbf{k g})$ & $\mathbf{\% D E}$ & $\mathbf{\% M E}$ \\
\hline $\mathbf{1}$ & 3687 & 3622 & 3895.22 & 3772.8 & 5.64 & 4.16 \\
$\mathbf{2}$ & 4036 & 3864 & 4031.00 & 3914.49 & -0.12 & 1.30 \\
$\mathbf{3}$ & 3843 & 3792 & 3927.15 & 3870.29 & 2.18 & 2.06 \\
$\mathbf{4}$ & 4057 & 4005 & 3969.94 & 3918.58 & -2.14 & -2.15 \\
$\mathbf{5}$ & 3974 & 3838 & 3924.55 & 3791.20 & -1.24 & -1.21 \\
\hline
\end{tabular}

DE: digestible energy; ME: metabolizable energy.

$\mathrm{DE}_{1}=11812-1015.9 \mathrm{CP}-837.9 \mathrm{EE}-1641 \mathrm{ADF}+2616.3 \mathrm{Ash}+47.5\left(\mathrm{CP}^{2}\right)+114.7\left(\mathrm{CF}^{2}\right)+46\left(\mathrm{ADF}^{2}\right)-1.6\left(\mathrm{NDF}^{2}\right)-997.1\left(\mathrm{Ash}^{2}\right)$ + 151.9EECF + 23.2EENDF - 126.4CPCF + 136.4CPADF - 4.0CPNDF;

$\mathrm{ME}_{1}=12574-1254.9 \mathrm{CP}-1140.5 \mathrm{EE}-1359.9 \mathrm{ADF}+2816.3 \mathrm{Ash}+77.6\left(\mathrm{CP}^{2}\right)+92.3\left(\mathrm{CF}^{2}\right)+54.1\left(\mathrm{ADF}^{2}\right)-1.8\left(\mathrm{NDF}^{2}\right)-1097.2\left(\mathrm{Ash}^{2}\right)$ $+240.6 \mathrm{EECF}+26.3 \mathrm{EENDF}-157.4 \mathrm{CPCF}+96.5 \mathrm{CPADF}-4.4 \mathrm{CPNDF}$.

The aim of the development of prediction equations was identificate of a model that uses a new sample of feedstuffs and offers greater accuracy in the measurement of DE and ME of corn for growing pigs. Thus, for validation of a model, estimation (as prediction of errors) should be conducted using new data; the validation cannot involve data from the same population where the equation was developed; this is because the latter approach may result in the selection of a model with lower accuracy (GAUCH; ZOBEL, 1988). Thus, in the present work, the validation of the equations was performed on corn samples not belonging to the original population. 


\section{Conclusion}

Using data on chemical composition, it was possible to develop prediction equations for DE and $\mathrm{ME}$ of corn for growing pigs; these equations seem to be valid because of the low prediction errors, ensuring high accuracy of the models.

\section{Acknowledgments}

We thank Embrapa Suínos e Aves for providing biological material, and $\mathrm{CNPq}$ (Conselho Nacional de Desenvolvimento Científico e Tecnológico, Brazil) for financial support.

\section{References}

AGUIRRE, L. Introdução à identificação de sistemas: técnicas lineares e não-lineares aplicadas a sistemas reais. 2 ed. Belo Horizonte: UFMG, 2004. 714 p.

ANDERSON, P. V.; KERR, B. J.; WEBER, T. E.; ZIEMER, C. J.; SHURSON, G. C. Determination and prediction of digestible and metabolizable energy from chemical analysis of corn co-products fed to growing pigs. Journal of Animal Science, Champaign, v. 90, n. 4, p. 1242-1254, 2012.

ASSOCIATION OF OFFICIAL ANALYTICAL CHEMISTS - AOAC. Official methods of analysis of the association analytical chemists. $18^{\text {th }}$ ed. Gaithersburg: Maryland, 2005. $1141 \mathrm{p}$.

CARRÉ, B. Prediction of the dietary energy value of poultry feeds. In: WISEMAN, J.; COLE, D. J. A. (Ed.). Feedstuff evaluation. London: Butterworths Heinemann, 1990. p. 283-300.

CASTILHA, L. D.; POZZA, P. C.; KLOSOWSKI, E. S.; NUNES, R. V.; LAZZERI, D. B.; POZZA, M. S. S.; RICHART, E. Modelos matemáticos para predição dos valores energéticos do milho para suínos. Revista Brasileira de Saúde e Produção Animal, Salvador, v. 12, n. 2, p. 456-467, 2011.

COSTA, M. A. L.; VALADARES FILHO, S. C.; DINIZ, R. V.; PAULINO, M. F.; CECON, P. R.; PAULINO, P. D. R.; CHIZZOTTI, M. L.; PAIXÃO, M. L. Validação das equações do NRC (2001) para predição do valor energético de alimentos nas condições brasileiras. Revista Brasileira de Zootecnia, Viçosa, MG, v. 34, n. 1, p. 280-287, 2005.
COWIESON, A. J. Factors that affect the nutritional value of maize for broilers. Animal Feed Science and Technology, Amsterdam, v. 119, n. 3, p. 293-305, 2005.

DRAPER, N. R.; SMITH, H. Applied regression analysis. $2^{\text {nd }}$ ed. New York: John Wiley, 1981. 709 p.

GAUCH, H. G.; ZOBEL, R. W. Predictive and postdictive success of statistical analysis of yield trials. Theoretical and Applied Genetics, Berlin, v. 76, n. 1, p. 1-10, 1988.

MATTERSON, L. D.; POTTER, L. M.; STUTZ, M. W.; SINGSEN, E. P. The metabolizable energy of feed ingredients for chickens. The University of Connecticut, Agricultural Experiment Station, Research Report, New Haven, v. 7, p. 3-11, 1965.

NASCIMENTO, G. A. J.; RODRIGUES, P. B.; FREITAS, R. T. F.; REIS NETO, R. V.; LIMA, R. R.; ALLAMAN, I. B. Equações de predição para estimar valores da energia metabolizável de alimentos concentrados energéticos para aves utilizando meta-análise. Arquivo Brasileiro de Medicina Veterinária e Zootecnia, Belo Horizonte, v. 63, n. 1, p. 222-230, 2011.

NRC. Nutrient requirements of swine. $11^{\text {th }}$ rev. ed. Washington, D. C.: National Academic Press, 2012. 400 p.

NOBLET, J.; PEREZ, J. M. Prediction of digestibility of nutrients and energy values of pig diets from chemical analysis. Journal of Animal Science, Champaign, v. 71, n. 12, p. 3389-3398, 1993.

PEDROSO, S.; EZEQUIEL, J.M.B.; OSUNA, J.T.A.; SANTOS, V.C.Características agronômicas e nutricionais de híbridos de milho e suas silagens (Zea mays L.). Revista ARS Veterinária, Jaboticabal, v. 22, n. 3, p. 248258, 2006.

POZZA, P. C.; GOMES, P. C.; DONZELE, J. L.; ROSTAGNO, H. S.; POZZA, M. S. S.; NUNES, R. V. Composição química, digestibilidade e predição dos valores energéticos da farinha de carne e ossos para suínos. Acta Scientiarum Animal Science, Maringá, v. 30, n. 1, p. 33-40, 2008.

ROSTAGNO, H. S.; ALBINO, L. F. T.; DONZELE, J. L.; GOMES, P. C.; OLIVEIRA, R. F.; LOPES, D. C.; FERREIRA, A. S.; BARRETO, L. S. T.; EUCLIDES, R. F. Tabelas brasileiras para aves e suínos: composição de alimentos e exigências nutricionais. 3. ed. Viçosa: Universidade Federal de Viçosa, 2011. 252 p.

STATISTICAL ANALYSIS SYSTEM INSTITUTE SAS Institute. SAS/STAT: user's guide. Version 9. 2. Cary: SAS Institute, 2009. 7869 p. 
VAN SOEST, P. J.; ROBERTSON, J. B.; LEWIS, B. A. Methods for dietary fiber, neutral detergent fiber, and nonstarch polysaccharides in relation to animal nutrition. Journal of Dairy Science, Madison, v. 74, n. 10, p. 35833597, 1991.

WISEMAN, J.; COLE, D. J. L. Predicting the energy content of pig feeds. In: COLE, D. J. A.; HARESIGN, W. (Ed.). Recent developments in pig nutrition. London: Burtterworth Heinemann, 1985. p. 59-70.
ZONTA, M. C. M.; RODRIGUES, P. B.; ZONTA, A.; FREITAS, R. T. F.; BERTECHINI, A. G.; FIALHO, E. T.; PEREIRA, C. R. Energia metabolizável de ingredientes protéicos determinada pelo método de coleta total e por equações de predição. Ciência e Agrotecnologia, Lavras, v. 28, n. 6 , p. 1400-1407, 2004. 
